\title{
Tuning the Reactivity of TEMPO during Electrocatalytic Alcohol Oxidations in Room-temperature Ionic Liquids
}

\author{
Astrid E. Delorme, ${ }^{1,2}$ Victor Sans, ${ }^{2,3}$ Peter Licence ${ }^{* 1,2}$ and Darren A. Walsh ${ }^{* 1,2}$ \\ ${ }^{1}$ School of Chemistry, University of Nottingham, University Park, Nottingham NG7 2RD, UK \\ ${ }^{2}$ GSK Carbon Neutral Laboratory for Sustainable Chemistry, University of Nottingham, Jubilee \\ Campus, Nottingham NG7 2TU, UK
}

${ }^{3}$ Faculty of Engineering, University of Nottingham, University Park, Nottingham NG7 2RD, UK

*email: darren.walsh@nottingham.ac.uk; Tel: 01158467495

*email: peter.licence@nottingham.ac.uk; Tel. 01158466176 


\begin{abstract}
2,2,6,6-tetramethylpiperidine-1-oxyl (TEMPO) is a promising, sustainable, metal-free mediator for oxidation of alcohols. In this contribution, we describe how the selectivity of TEMPO for electrocatalytic alcohol oxidations in room-temperature ionic liquids (RTILs) can be changed by design of the solvent medium. Cyclic voltammetry of TEMPO in a series of ammonium-, phosphonium-, and imidazolium-based RTILs reveals that the potential at which TEMPO is oxidized increases from $677 \mathrm{mV}$ (vs. the potential of the decamethylferrocene/ decamethylferrocinium, $\mathrm{dmFc} / \mathrm{dmFc}^{+}$, redox couple) to $788 \mathrm{mV}$ as the $\mathrm{H}$-bond basicity of the RTIL anions decreases. The increase in potential is accompanied by an increase in the rate constant for oxidation of benzyl alcohol from about $0.1 \mathrm{dm}^{3} \mathrm{~mol}^{-1} \mathrm{~s}^{-1}$ to about $0.7 \mathrm{dm}^{3} \mathrm{~mol}^{-1} \mathrm{~s}^{-1}$, demonstrating the ability to manipulate the reactivity of TEMPO by judicious choice of the RTIL anions. The rate of alcohol oxidation in a series of RTILs increases in the order 2-butanol $<1$ phenylethanol $<$ octanol $<$ benzyl alcohol, and the RTIL 1-octyl-3-methylmidazolium bis(trifluoromethanesulfonyl)imide $\left(\left[\mathrm{NTf}_{2}\right]^{-}\right)$shows clear selectivity towards the oxidation of primary alcohols. In addition, the reaction kinetics and selectivity are better in $\left[\mathrm{NTf}_{2}\right]^{-}$-based RTILs than in acetonitrile, often the solvent-of-choice in indirect alcohol electrooxidations. Finally, we demonstrate that electrolytic TEMPO-mediated alcohol oxidations can be performed using RTILs in a flow-electrolysis system, with excellent yields and reaction selectivity, demonstrating the opportunities offered by such systems.
\end{abstract}




\section{INTRODUCTION}

The oxidation of alcohols is one of the most widely used industrial transformations. However, traditional methods for oxidizing alcohols are often energetically demanding, suffer from poor atom efficiencies, require harsh reaction conditions, and generate significant amounts of potentially hazardous wastes. ${ }^{1-3}$ Consequently, the development of clean and sustainable methods for oxidizing alcohols is of increasing importance to the chemical-using industries. ${ }^{4,5}$ 2,2,6,6,-tetramethylpiperidine-1-oxyl (TEMPO) is a metal-free, sustainable alternative to traditional reagents for the oxidation of primary and secondary alcohols to carbonyl compounds, and which attracted increasing interest in this context in recent years. ${ }^{6-8}$

As well as growing interest in the development of sustainable processes for the chemicalusing industry, there is increasing interest in the development of sustainable electrosynthetic methods, which offer the prospects of high atom economy and cleanliness. The renaissance in the use of electrosynthetic methods is also being driven by increasing availability and accessibility of electrochemical equipment. $^{9-11}$ Electrochemical methods have been used in TEMPO-mediated oxidations as the catalytically-active oxoammonium species $\left(\mathrm{TEMPO}^{+}\right)$can be formed electrochemically using simple carbon electrodes held at positive potentials. This approach eliminates the requirement for dedicated molecular oxidants such as hypervalent iodine ${ }^{3}$ and bleach ${ }^{12}$, and increases the sustainability of the process. ${ }^{13}$ Despite these advantages, unfamiliarity with electrosynthetic methods, as well as the use of volatile organic solvents and expensive supporting electrolytes may be contributing the slow uptake of electrosynthesis for industrial-scale processes. $^{11}$

Room temperature ionic liquids (RTILs) are salts that are liquid below $100{ }^{\circ} \mathrm{C}$, inherently conductive, non-volatile, and generally more electrochemically stable than conventional solvents 
such as acetonitrile. The unique properties of RTILs offer clear advantages during the development of electrosynthetic processes, due to their stability and the fact that they can be used as both the solvent and electrolyte. ${ }^{14,15}$ RTILs can also be used as dissolved electrolytes, which in some cases has improved the efficiency of electrochemical reactions. For example, addition of the 1-ethyl-3methylimidazolium methanesulfonate to alkaline water improved water electrolysis significantly. ${ }^{16}$ A particularly attractive feature of RTILs is the ability to tune their physicochemical and electrochemical properties by judicious choice of the cations and anions (leading to their labelling as "designer" solvents). ${ }^{17}$ For example, the rates of mass transfer of redox species to electrodes in RTILs can be changed significantly by altering the ionic composition of RTILs; significant differences in the rates of mass transfer of a single redox couple in different oxidation states in an RTIL have even been observed. ${ }^{18}$ The redox reactivity of solutes can also be changed by varying the composition of RTILs; for example, the redox potentials of 2,2-diphenyl1-picylhydrazyl (DPPH) ${ }^{19}$ and 1,2-diferrocenylethylene ${ }^{20}$ in RTILs have been tuned by varying the RTIL anions. In this context, the possibility of tuning the reactivity and selectivity of TEMPO by using RTIL electrolytes is attractive, as it can potentially provide a means to boosting the performance of TEMPO-mediated alcohol oxidations.

A handful of studies on the electrochemical behavior of TEMPO in RTILs have been conducted, and demonstrate that the behavior of TEMPO in RTILs is similar to that in acetonitrile and water. Doherty and coworkers observed that the global rate constant of TEMPO-mediated alcohol oxidation was a factor of six larger in $N$-butyl- $N$-methyl pyrrolidinium than in acetonitrile, despite the fact that mass transfer was slower in the RTIL. ${ }^{21,22}$ These experiments show that, not only is the use of RTILs advantageous in terms of eliminating the need for volatile molecular solvents and extraneous electrolytes, but also for the efficiency of the alcohol oxidations. 
In this contribution, we describe tuning the reactivity and selectivity of RTILs for TEMPOmediated electrooxidations, by changing RTIL parameters such as the length of alkyl chains, the presence of aromatic rings, and the H-bond basicity of the anions. We first describe changes in the redox properties of TEMPO in a series of imidazolium-, pyrrolidinium-, phosphonium- and ammonium-based RTILs (Table 1). Voltammetric analysis shows that the TEMPO/TEMPO ${ }^{+}$ redox potential depends on the choice of RTIL anion, due to differing degrees of stabilization of the TEMPO ${ }^{+}$cation within the RTILs. This tuning of the redox properties of TEMPO in turn affects the rates of alcohol oxidation in the RTILs. We then demonstrate that the use of RTILs allows the introduction of kinetic selectivity into the oxidation of primary and secondary alcohols. To allow comparison with conventional systems, we also describe the effects of using RTILs as dissolved electrolytes in acetonitrile during alcohol oxidations. Our studies show that stabilization

of TEMPO ${ }^{+}$by the RTIL anions is also observed when the RTILs are dissolved. Moreover, the identity and concentration of the dissolved RTIL clearly affect the rates of alcohol oxidations, demonstrating that tuning the electrolyte is also important when using conventional solvents. Finally, we show that RTILs can be used as the solvents during alcohol oxidation in an electrochemical flow system, with excellent yields and selectivities.

\section{EXPERIMENTAL METHODS}

Reagents and Apparatus. Reagents were obtained from Sigma-Aldrich and Alfa-Aesar and were used as received. RTILs were prepared according to literature procedures ${ }^{23,24}$ and were characterized using ${ }^{1} \mathrm{H},{ }^{13} \mathrm{C},{ }^{19} \mathrm{~F}$ and ${ }^{31} \mathrm{P}$ NMR spectroscopy (Bruker DPX-400 Spectrometer), electrospray-ionisation mass spectrometry (Bruker MicroTOF spectrometer), and elemental analysis. All RTILs were dried under vacuum $\left(10^{-4}-10^{-6} \mathrm{mbar}\right)$ and stored under Ar prior to use. 
Residual $\mathrm{H}_{2} \mathrm{O}$ contents of RTILs were measured using Karl-Fisher analysis and were $<200$ ppm. RTILs were free of residual halides (according to analysis using a DIONEX ICS-5000 $0^{+}$ion chromatograph). Cyclic voltammetry was performed using an Autolab PGSTAT302 (EcoChemie, the Netherlands) and CHI760 potentiostat (From CH Instruments Austin, USA).

Table 1. RTIL cations and anions used in this study

\begin{tabular}{|c|c|c|}
\hline Abbreviations & Structure & Name \\
\hline$\left[\mathrm{C}_{n} \mathrm{C}_{1} \mathrm{Pyrr}\right]+$ & & 1-alkyl-1-methylpyrrolidinium \\
\hline$\left[\mathrm{C}_{n} \mathrm{C}_{1} \mathrm{Im}\right]^{+}$ & $\mathrm{H}_{2}$ & 1-alkyl-3-methylimidazolium \\
\hline$\left[\mathrm{NR}_{4}\right]^{+}$ & $\begin{array}{lllll}R_{3} & R_{2} \\
R_{2}\end{array}$ & $\mathrm{~N}, \mathrm{~N}, \mathrm{~N}, \mathrm{~N}$ - tetraalkylammonium \\
\hline$\left[\mathrm{PR}_{4}\right]^{+}$ & & $\mathrm{N}, \mathrm{N}, \mathrm{N}, \mathrm{N}$ - tetraalkylphosphonium \\
\hline$\left[\mathrm{NTf}_{2}\right]^{-}$ & & bis(trifluoromethanesulfonyl)-imide \\
\hline$\left[\mathrm{PF}_{6}\right]^{-}$ & & hexafluorophosphate \\
\hline$[\mathrm{OTf}]^{-}$ & & trifluoromethanesulfonate \\
\hline$[\mathrm{DCA}]^{-}$ & & dicyanamide \\
\hline$\left[\mathrm{MeOSO}_{3}\right]^{-}$ & & methylsulfate \\
\hline
\end{tabular}


Diffusion Measurements. Diffusion coefficients of benzyl alcohol in the reaction solutions were determined using pulse-field gradient nuclear magnetic resonance (PFG-NMR) spectroscopy. Measurements were performed using a Bruker DPX-400 spectrometer, operating at $400.13 \mathrm{MHz}\left({ }^{1} \mathrm{H}\right)$. A solution containing $0.6 \mathrm{~mol} \mathrm{dm}^{-3}$ benzyl alcohol and $2.4 \mathrm{~mol} \mathrm{dm}^{-3}$ 2,6-lutidine in the appropriate RTIL were added to the coaxial insert, which was then added into the sample tube with deuterated acetone. Each measurement was performed in triplicate.

Electrochemical Methods. A three-electrode electrochemical cell consisting of a 3-mm diameter glassy carbon (GC) disk working electrode, a Pt-flag counter electrode, and Ag-wire quasi-reference electrode were used for electrochemical measurements. $5 \mathrm{mmol} \mathrm{dm}{ }^{-3}$ decamethylferrocene $(\mathrm{dmFc})$, which has been proposed as a more reliable internal reference redox couple for ionic-liquid electrochemistry than the commonly-used ferrocene/ferrocinium $\left(\mathrm{Fc} / \mathrm{Fc}^{+}\right)$ couple,${ }^{20,25}$ was used as the internal standard during voltammetry of RTILs. Prior to use, the GC electrode was polished using an aqueous suspension of $0.05-\mu \mathrm{m}$ alumina and rinsed thoroughly with ultrapure $\mathrm{H}_{2} \mathrm{O}$. All solutions were deoxygenated prior to use by bubbling with Ar for at least 10 min. Compensation for uncompensated ohmic resistance was performed during each measurement using positive-feedback correction.

Flow electrolyses were performed in an Ammonite8 cell from Cambridge Reactor Design (Cambridgeshire, UK). $2 \mathrm{~cm}^{3}$ of $0.2 \mathrm{~mol} \mathrm{dm}^{-3}$ alcohol, $2.4 \mathrm{~mol} \mathrm{dm}^{-3}$ 2,6-lutidine, $0.06 \mathrm{~mol}$ $\mathrm{dm}^{-3}$ TEMPO and $0.4 \mathrm{~mol} \mathrm{dm}^{-3}$ tert-butylbenzene (as the internal standard for GC-MS monitoring) were dissolved in the appropriate RTIL. $2 \mathrm{~cm}^{3}$ of $\mathrm{H}_{2} \mathrm{O}$ was added to provide protons for the $\mathrm{H}_{2}$ evolution reaction at the cathode. $1 \mathrm{~cm}^{3}$ of the solution was pumped through the cell at $0.05 \mathrm{~cm}^{3} \mathrm{~min}^{-1}$ and electrolysis was carried out under constant current densities $\left(0.5 \mathrm{~mA} \mathrm{~cm}{ }^{-2}, 1\right.$ $\mathrm{mA} \mathrm{cm}{ }^{-2}, 1.5 \mathrm{~mA} \mathrm{~cm}^{-2}$ or $2 \mathrm{~mA} \mathrm{~cm}^{-2}$ ). Products were collected from the cell outlet and were 
$\mathrm{cm}^{-3}$ of toluene for analysis by gas chromatography using a flame ionization detector.

\section{RESULTS AND DISCUSSION}

Electrochemical Behavior of TEMPO in RTILs. Figure 1 shows a cyclic voltammogram $(\mathrm{CV})$ of TEMPO in $\left[\mathrm{C}_{8} \mathrm{C}_{1} \mathrm{Pyrr}\right]\left[\mathrm{NTf}_{2}\right]$. Anodic and cathodic peaks due to oxidation of TEMPO and reduction of $\mathrm{TEMPO}^{+}$are labeled a and c, respectively. Anodic and cathodic peaks due to oxidation of $\mathrm{dmFc}$ to $\mathrm{dmFc}^{+}$, and reduction of $\mathrm{dmFc}^{+}$, are also visible. ${ }^{25} \mathrm{The} \mathrm{CV}$ is representative of those of TEMPO dissolved in each RTIL (Figures S2-S13 in the supporting information). In all cases, the ratio of the anodic to cathodic peak current, $i_{\mathrm{p}, \mathrm{a}} / i_{\mathrm{p}, \mathrm{c}}$, for TEMPO/TEMPO ${ }^{+}$ oxidation/reduction is close to unity, and $i_{\mathrm{p}, \mathrm{a}}$ and $i_{\mathrm{p}, \mathrm{c}}$ are proportional to the square root of the voltammetric scan rate, $v^{1 / 2}$, as expected for freely-diffusing, electrochemically-reversible, redox couples. Such electrochemical reversibility has also been observed previously during voltammetry of TEMPO in organic ${ }^{21,22,26}$, aqueous ${ }^{27,28}$, and RTIL electrolytes. ${ }^{21,22}$ The separation between the anodic and cathodic peak potentials, $\Delta E_{\mathrm{p}}$, for TEMPO oxidation/reduction in each RTIL is $60-70$ $\mathrm{mV}$, which is slightly higher than expected for an electrochemically-reversible system involving the transfer of a single electron $(59 \mathrm{mV})$. Given that ohmic-drop compensation was performed using positive-feedback correction during all voltammetric measurements, the high $\Delta E_{\mathrm{p}}$ is attributed to sluggish electron-transfer kinetics across the electrode/RTIL interface, as observed previously when performing cyclic voltammetry using RTIL electrolytes. ${ }^{29}$

The most notable observation from the cyclic voltammetry of TEMPO is that the potential of the TEMPO/TEMPO ${ }^{+}$redox couple varies as the composition of the RTIL changes. The $\mathrm{TEMPO} \mathrm{TEMPO}^{+}$mid-point potential varies from $677 \mathrm{mV}$ to $788 \mathrm{mV} v s . \mathrm{dmFc} / \mathrm{dmFc}^{+}$as the 
composition of the RTIL changes (Figure 2). This shift can be explained by considering the

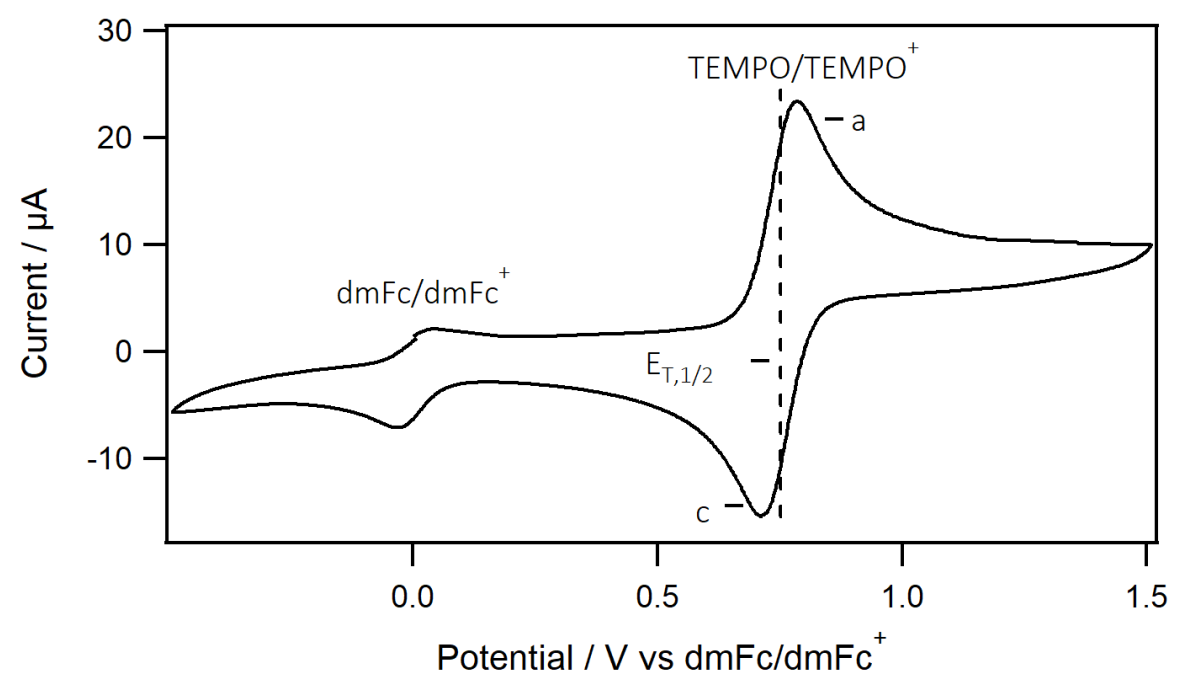

Figure 1. Cyclic voltammogram of $5 \mathrm{mmol} \mathrm{dm}^{-3}$ decamethylferrocene and $10 \mathrm{mmol} \mathrm{dm}^{-3} \mathrm{TEMPO}$ in $\left[\mathrm{C}_{8} \mathrm{C}_{1} \mathrm{Pyrr}\right]\left[\mathrm{NTf}_{2}\right]$, recorded using a 3-mm diameter glassy-carbon electrode at $50 \mathrm{mV} \mathrm{s}^{-1}$.

solvent properties of the RTILs, polar solvents that can act as H-bond donors and H-bond acceptors. The Kamlet-Taft parameters are commonly used to describe the solvent properties of RTILs in terms of the H-bond basicity $(\beta)$, H-bond acidity $(\alpha)$, and dipolarity/polarizability $\left(\pi^{*}\right) .{ }^{30}$ For RTILs with $\beta>0.5$, the TEMPO/TEMPO ${ }^{+}$mid-point potential decreases linearly as $\beta$ increases ( $\beta$ values were obtained from References 30 and 31), indicating that the interaction between the electron-deficient TEMPO $^{+}$and RTIL-anions becomes stronger as the RTIL anions become more basic (Figure 2). In general, the relatively bulky $\left[\mathrm{NTf}_{2}\right]^{-}$anions stabilize $\mathrm{TEMPO}^{+}$to a lesser extent than the more basic $[\mathrm{DCA}]^{-}$ions. In the following sections we investigate the effects of this stabilization on TEMPO-mediated alcohol oxidations. 


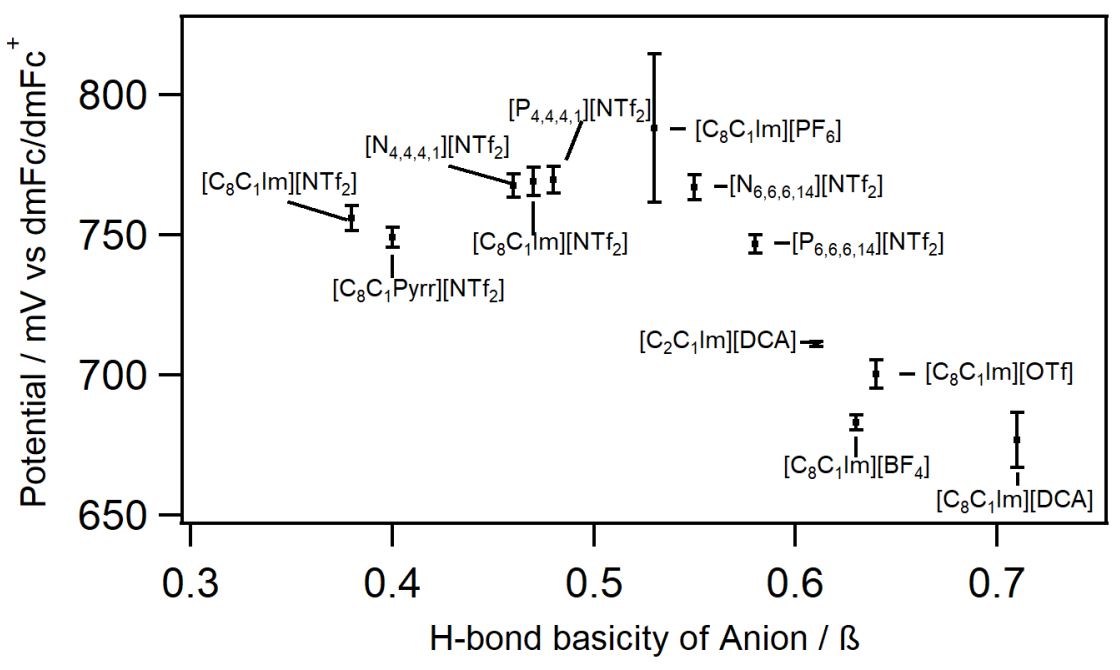

Figure 2. Correlation between the measured mid-point potential of the TEMPO/TEMPO ${ }^{+}$redox couple and the H-bond basicity of the anions, $\beta$, which were obtained from References 30 and 31.

TEMPO-mediated Alcohol Oxidation in RTILs. Figure 3 shows the effects of adding benzyl alcohol and 2,6-lutidine on the voltammetry of TEMPO in $\left[\mathrm{C}_{8} \mathrm{C}_{1} \operatorname{Im}\right]\left[\mathrm{NTf}_{2}\right]$. In this instance, ferrocene was used as the internal standard, due to the instability of decamethylferrocene in air. The green line is the CV of TEMPO in the RTIL. Addition of $2.0 \mathrm{mmol} \mathrm{dm}^{-3} 2,6$-lutidine to the solution causes $i_{\mathrm{p}, \mathrm{a}}$ and $i_{\mathrm{p}, \mathrm{c}}$ to increase, due to the slight decrease in viscosity of the RTIL (blue line). ${ }^{21,22}$ Addition of benzyl alcohol to the TEMPO-RTIL solution (red line) causes a slight increase in $i_{\mathrm{p}, \mathrm{a}}$ and decrease in $i_{\mathrm{p}, \mathrm{c}}$. The decrease in $i_{\mathrm{p}, \mathrm{c}}$ suggests that some of the TEMPO ${ }^{+}$was reduced back to TEMPO by the alcohol oxidation. However, this effect is only observed at low scan rates $\left(<50 \mathrm{mV} \mathrm{s}^{-1}\right)$, suggesting that $\mathrm{TEMPO}^{+}$only react very slowly in the presence of alcohol. When TEMPO, benzyl alcohol, and 2,6-lutidine are present together, $i_{\mathrm{p}, \mathrm{a}}$ increases drastically and $i_{\mathrm{p}, \mathrm{c}}$ decreases to a negligible level, as a result of the catalytic reaction between TEMPO ${ }^{+}$and benzyl alcohol producing benzaldehyde..$^{21,22}$ 


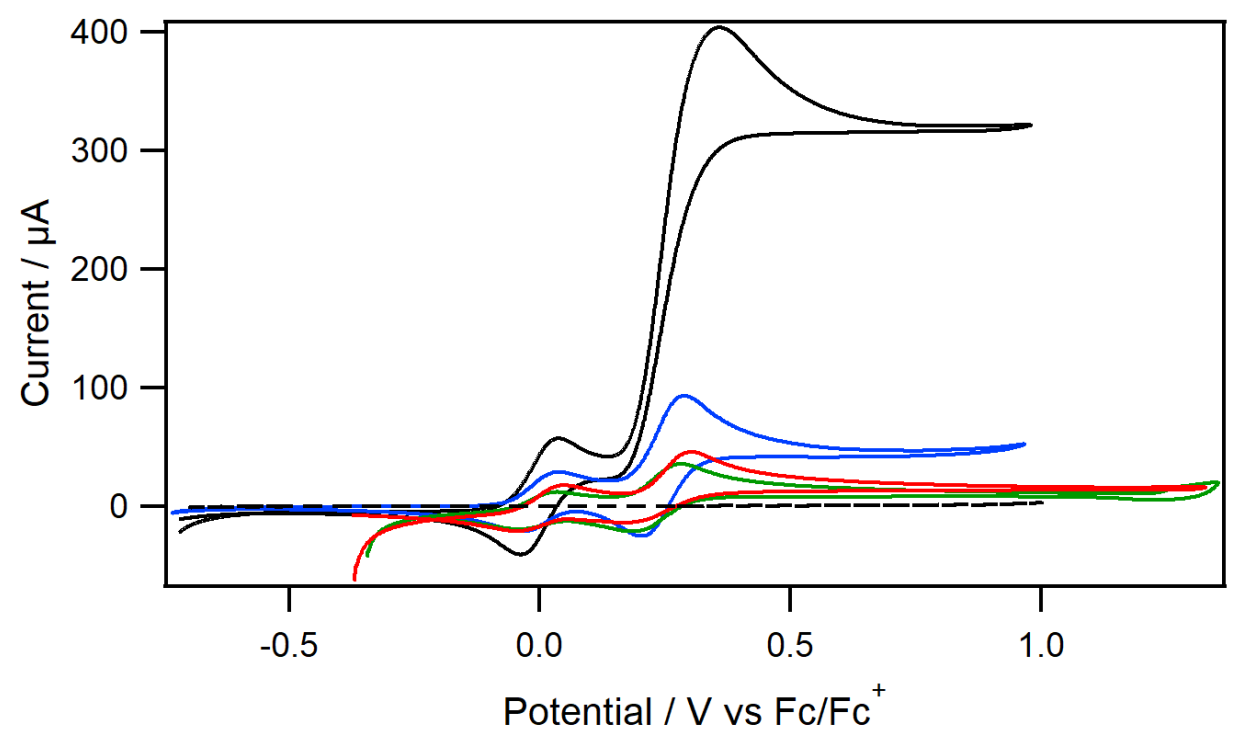

Figure 3. CV of $60 \mathrm{mmol} \mathrm{dm}^{-3}$ TEMPO (green). The red line is the $\mathrm{CV}$ of $60 \mathrm{mmol} \mathrm{dm}^{-3} \mathrm{TEMPO}$ $+0.6 \mathrm{~mol} \mathrm{dm}^{-3}$ benzyl alcohol. The blue line is the $\mathrm{CV}$ of $60 \mathrm{mmol} \mathrm{dm}^{-3}$ TEMPO $+2.0 \mathrm{~mol} \mathrm{dm}^{-3}$ 2,6-lutidine. The black line is the $\mathrm{CV}$ of $60 \mathrm{mmol} \mathrm{dm}^{-3} \mathrm{TEMPO}+0.6 \mathrm{~mol} \mathrm{dm}^{-3}$ benzyl alcohol + $2.0 \mathrm{~mol} \mathrm{dm}^{-3}$ 2,6-lutidine. All CVs were recorded at $5 \mathrm{mV} \mathrm{s}^{-1}$ using a 3-mm diameter glassycarbon working electrode and $\left[\mathrm{C}_{8} \mathrm{C}_{1} \mathrm{Im}\right]\left[\mathrm{NTf}_{2}\right]$ as the solvent.

We examined the effect of changing the RTIL composition on the electrocatalysis of alcohol oxidation, and the CVs of 2,6-lutidine, benzyl alcohol, and TEMPO recorded using $\left[\mathrm{C}_{2} \mathrm{C}_{1} \operatorname{Im}\right]\left[\mathrm{NTf}_{2}\right]$ and $\left[\mathrm{C}_{2} \mathrm{C}_{1} \mathrm{Im}\right][\mathrm{DCA}]$ as the solvent are compared in Figure 4. While the diffusion coefficient of benzyl alcohol, $D$, in the $\left[\mathrm{C}_{2} \mathrm{C}_{1} \mathrm{Im}\right][\mathrm{DCA}] / 2.4 \mathrm{~mol} \mathrm{dm}^{-3} 2,6$-lutidine $/ 0.6 \mathrm{~mol} \mathrm{dm}^{-3}$ benzyl alcohol solution is slightly higher $\left(D=1.244 \times 10^{-10} \pm 0.061 \times 10^{-10} \mathrm{~cm}^{2} \mathrm{~s}^{-1}\right)$ than in the $\left[\mathrm{C}_{2} \mathrm{C}_{1} \mathrm{Im}\right]\left[\mathrm{NTf}_{2}\right] / 2.4 \mathrm{~mol} \mathrm{dm}^{-3}$ 2,6-lutidine $/ 0.6 \mathrm{~mol} \mathrm{dm}^{-3}$ benzyl alcohol solution $(D=1.171 \times$ $\left.10^{-10} \pm 0.055 \times 10^{-10} \mathrm{~cm}^{2} \mathrm{~s}^{-1}\right)$, the catalytic current, $i_{\text {cat }}$, is much higher in the $\left[\mathrm{C}_{2} \mathrm{C}_{1} \operatorname{Im}\right]\left[\mathrm{NTf}_{2}\right]$ solution than in the $\left[\mathrm{C}_{2} \mathrm{C}_{1} \mathrm{Im}\right][\mathrm{DCA}]$ solution. Equation 1 shows the relationship between $i_{\text {cat }}$ and $D$, where $C_{\mathrm{T}}$ is the bulk concentration of TEMPO, $n$ is the number of electrons involved in one catalytic cycle ( 2 in this case), $F$ is the Faraday constant, $A$ the surface area of the working 
electrode, $k$ is the reaction rate constant, and $C_{\mathrm{A}}$ is the bulk concentration of the alcohol. The increase in $i_{\text {cat }}$ upon changing from $\left[\mathrm{C}_{2} \mathrm{C}_{1} \mathrm{Im}\right][\mathrm{DCA}]$ to $\left[\mathrm{C}_{2} \mathrm{C}_{1} \operatorname{Im}\right]\left[\mathrm{NTf}_{2}\right]$ is higher than expected from Equation 1, indicating that changing the RTIL composition changes $k$.

$i_{\text {cat }}=n A F C_{\mathrm{T}}\left(D k C_{\mathrm{A}}\right)^{1 / 2}$

The relationship between $i_{\text {cat }}$ and $C_{\mathrm{A}}$ was then explored and Figure 5 shows CVs of solutions containing TEMPO, 2,6-lutidine and different concentrations of benzyl alcohol in $\left[\mathrm{C}_{8} \mathrm{C}_{1} \mathrm{Im}\right]\left[\mathrm{NTf}_{2}\right] . \quad i_{\text {cat }}$ increases linearly with $C_{\mathrm{A}}{ }^{1 / 2}$ in agreement with Equation 1 (Figure 5 inset). ${ }^{32,33}$ All of the TEMPO-RTIL systems containing 2,6-lutidine and varying $C_{\mathrm{A}}$ values yielded an $i_{\text {cat }}$ that was depended linearly on $C_{\mathrm{A}}{ }^{1 / 2} . k$ can be derived from the slope of the linear plots of $i_{\text {cat }}$ vs. $C_{\mathrm{A}}{ }^{1 / 2}$ and Figure 6 shows that $k$ generally decreases as the TEMPO-oxidation potential decreases. This decrease indicates that stabilization of $\mathrm{TEMPO}^{+}$by the more basic anions decreases the availability of $\mathrm{TEMPO}^{+}$to take part in the catalytic cycle. $k$ was generally higher in the RTILs containing the relatively-acidic, bulky $\left[\mathrm{NTf}_{2}\right]^{-}$anions $\left(\sim 0.5-0.8 \mathrm{dm}^{3} \mathrm{~mol}^{-1} \mathrm{~s}^{-1}\right.$ - red bars in Figure 6) than in, for example, a relatively basic RTIL such as $\left[\mathrm{C}_{8} \mathrm{C}_{1} \mathrm{Im}\right][\mathrm{DCA}]\left(\sim 0.1 \mathrm{dm}^{3} \mathrm{~mol}^{-}\right.$ ${ }^{1} \mathrm{~s}^{-1}$ ). While any relationship between $k$ and the RTIL-cation identity is less clear, $k$ is generally lower when using those liquids containing imidazolium cations, whereas use of the bulkier quaternary phosphonium- and ammonium-based RTILs leads to the higher rate constants. The more exposed charge on the imidazolium-based cations may disfavor formation of the positivelycharged $\mathrm{TEMPO}^{+}$. These results demonstrate that it is possible to control the reactivity/efficiency of TEMPO-mediated alcohol oxidations simply by changing the structure of the RTIL media. 


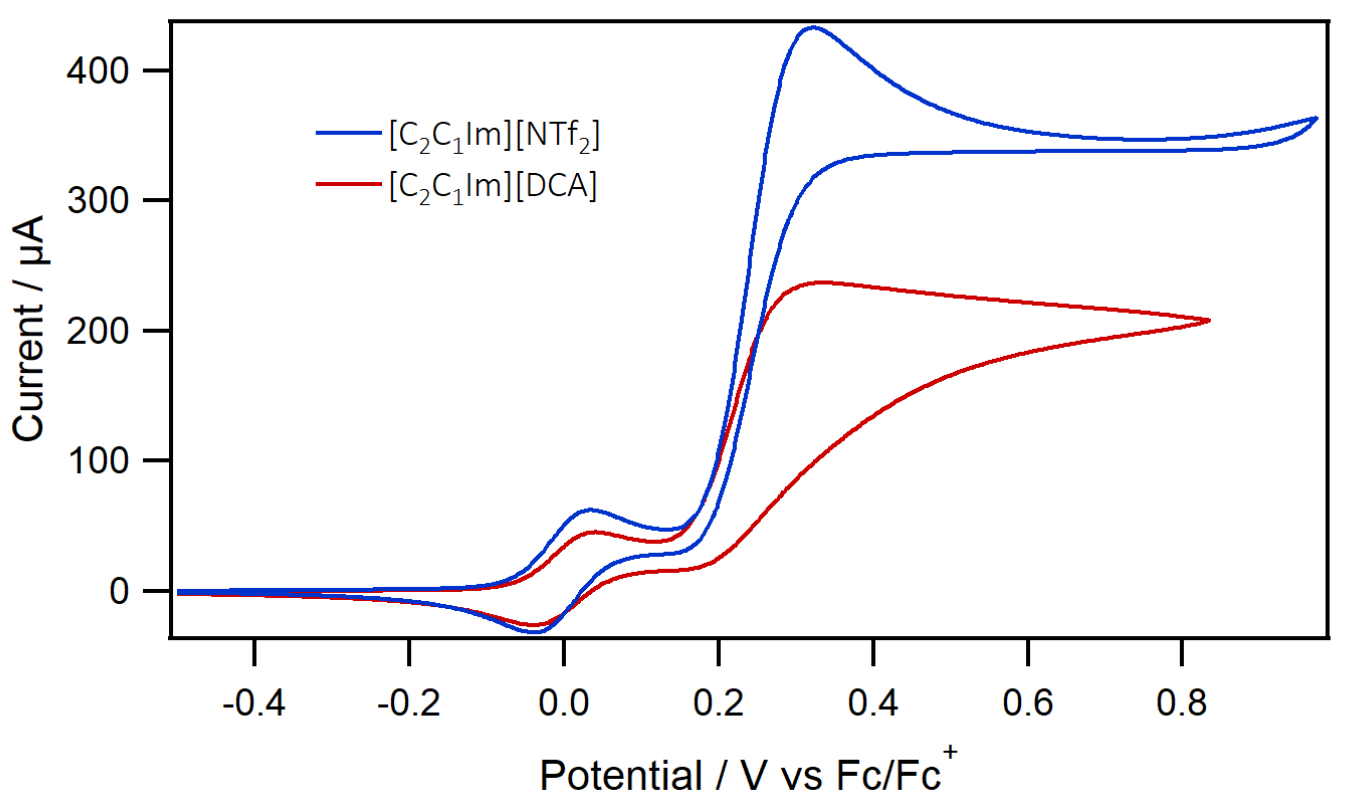

Figure 4. CVs of $60 \mathrm{mmol} \mathrm{dm}^{-3}$ TEMPO, $0.6 \mathrm{~mol} \mathrm{dm}^{-3}$ benzyl alcohol, and $2.4 \mathrm{~mol} \mathrm{dm}^{-3} 2,6-$ lutidine in $\left[\mathrm{C}_{2} \mathrm{C}_{1} \mathrm{Im}\right]\left[\mathrm{NTf}_{2}\right]$ (blue line) and $\left[\mathrm{C}_{2} \mathrm{C}_{1} \mathrm{Im}\right][\mathrm{DCA}]$ (red line) recorded at $5 \mathrm{mV} \mathrm{s}^{-1}$.

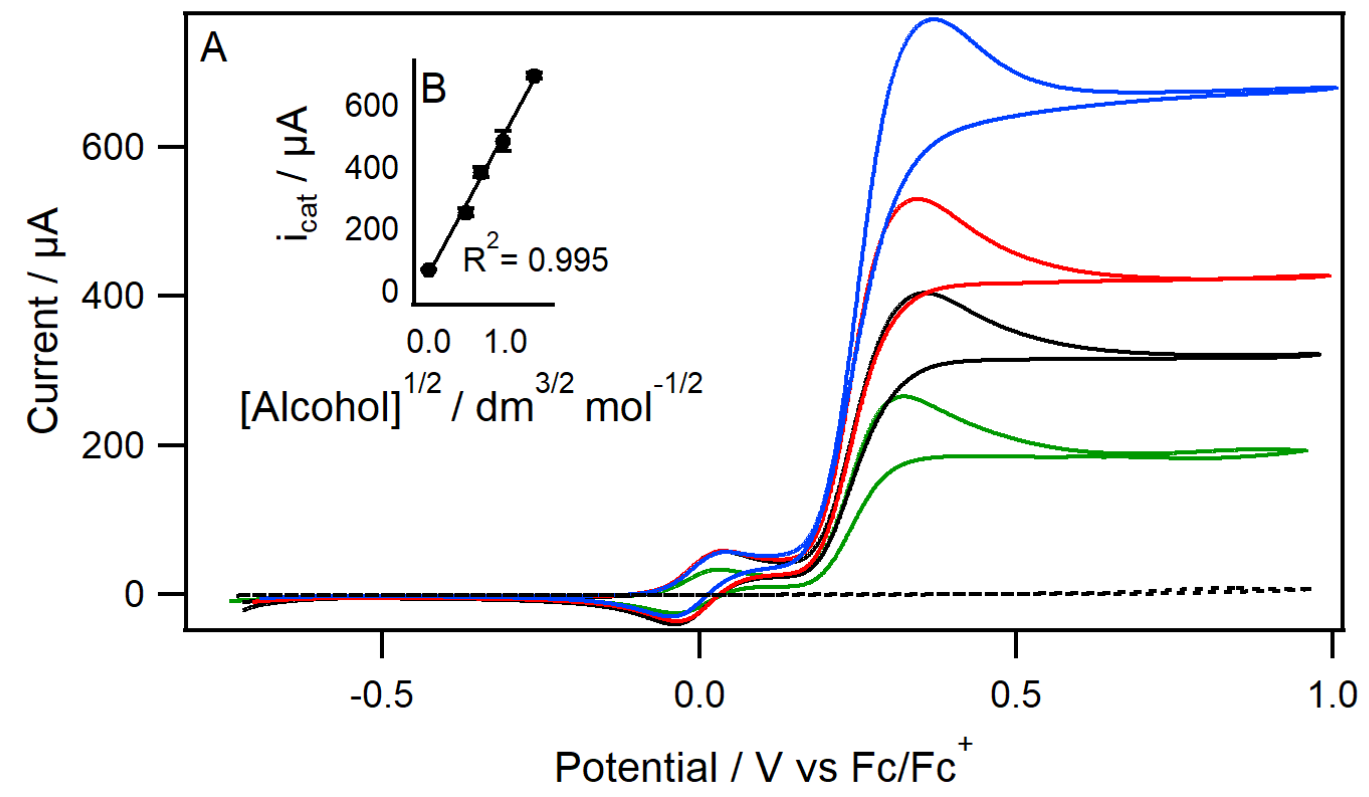

Figure 5. CVs of $60 \mathrm{mmol} \mathrm{dm}^{-3}$ TEMPO and $2.4 \mathrm{~mol} \mathrm{dm}^{-3}$ 2,6-lutidine dissolved in [ $\left.\mathrm{C}_{8} \mathrm{C}_{1} \mathrm{Im}\right]\left[\mathrm{NTf}_{2}\right]$ containing $0.30 \mathrm{~mol} \mathrm{dm}^{-3}$ (green), $0.6 \mathrm{~mol} \mathrm{dm}^{-3}$ (black), $1.2 \mathrm{~mol} \mathrm{dm}^{-3}$ (red) and $2.4 \mathrm{~mol} \mathrm{dm}^{-3}$ (blue) benzyl alcohol. The inset shows a graph of the $i_{\text {cat }}$ vs. $C_{\mathrm{A}}{ }^{1 / 2}$. 


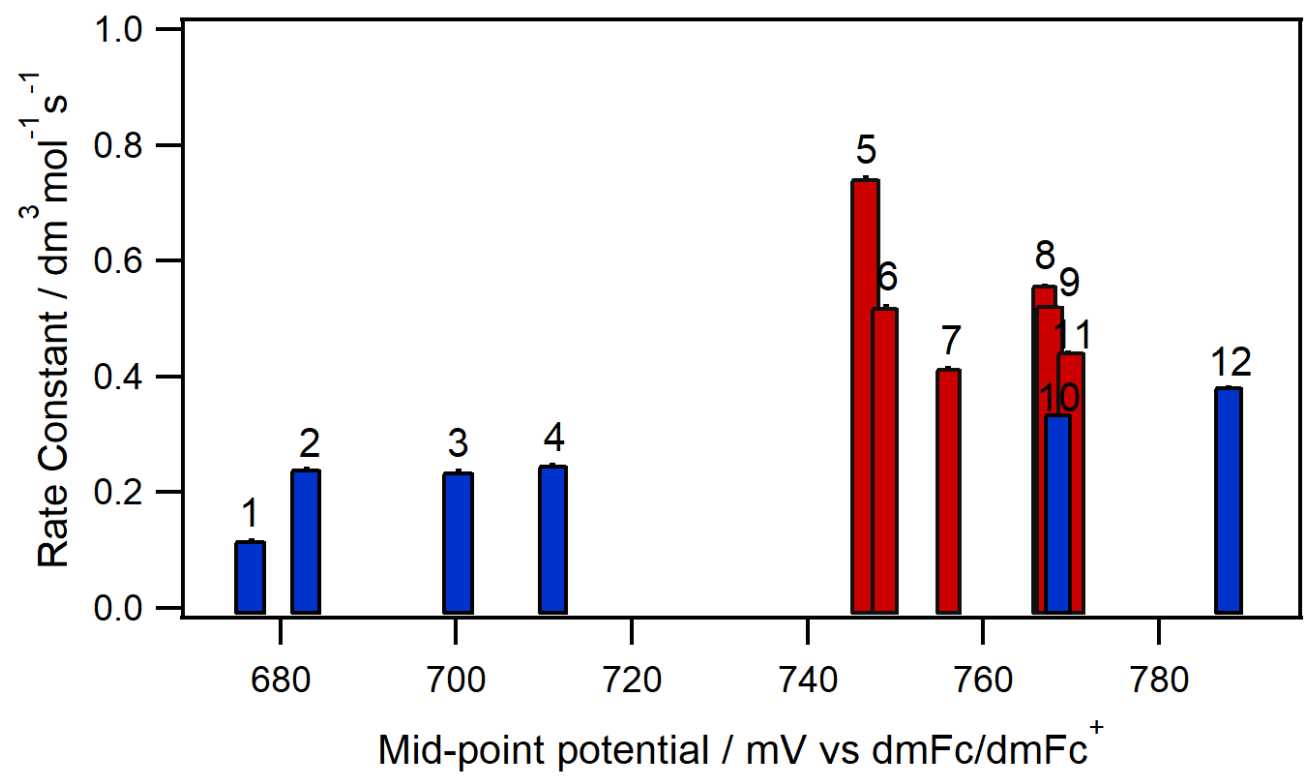

Figure 6. Correlation between the midpoint potential of TEMPO/TEMPO ${ }^{+}$and the rate constants of the TEMPO-mediated alcohol oxidations. The maximum errors in the rate constant and the midpoint potentials are estimated as $\pm 0.009 \mathrm{dm}^{-3} \mathrm{~mol}^{-1} \mathrm{~s}^{-1}$ and $\pm 7 \mathrm{mV}$. The RTILs are 1$\left[\mathrm{C}_{8} \mathrm{C}_{1} \mathrm{Im}\right][\mathrm{DCA}], 2-\left[\mathrm{C}_{8} \mathrm{C}_{1} \mathrm{Im}\right]\left[\mathrm{BF}_{4}\right], 3-\left[\mathrm{C}_{8} \mathrm{C}_{1} \mathrm{Im}\right][\mathrm{OTf}], 4-\left[\mathrm{C}_{2} \mathrm{C}_{1} \mathrm{Im}\right][\mathrm{DCA}], 5-\left[\mathrm{P}_{6,6,6,14}\right]\left[\mathrm{NTf}_{2}\right], 6-$ $\left[\mathrm{C}_{8} \mathrm{C}_{1} \mathrm{Pyrr}\right]\left[\mathrm{NTf}_{2}\right], 7-\left[\mathrm{C}_{2} \mathrm{C}_{1} \mathrm{Im}\right]\left[\mathrm{NTf}_{2}\right], 8-\left[\mathrm{N}_{6,6,6,14}\right]\left[\mathrm{NTf}_{2}\right], 9-\left[\mathrm{N}_{4,4,4,1}\right]\left[\mathrm{NTf}_{2}\right], \quad 10-\left[\mathrm{C}_{8} \mathrm{C}_{1} \mathrm{Im}_{[}\right]\left[\mathrm{NTf}_{2}\right]$, $11-\left[\mathrm{P}_{, 4,4,1}\right]\left[\mathrm{NTf}_{2}\right]$, and $12-\left[\mathrm{C}_{8} \mathrm{C}_{1} \operatorname{Im}\right]\left[\mathrm{PF}_{6}\right]$. 

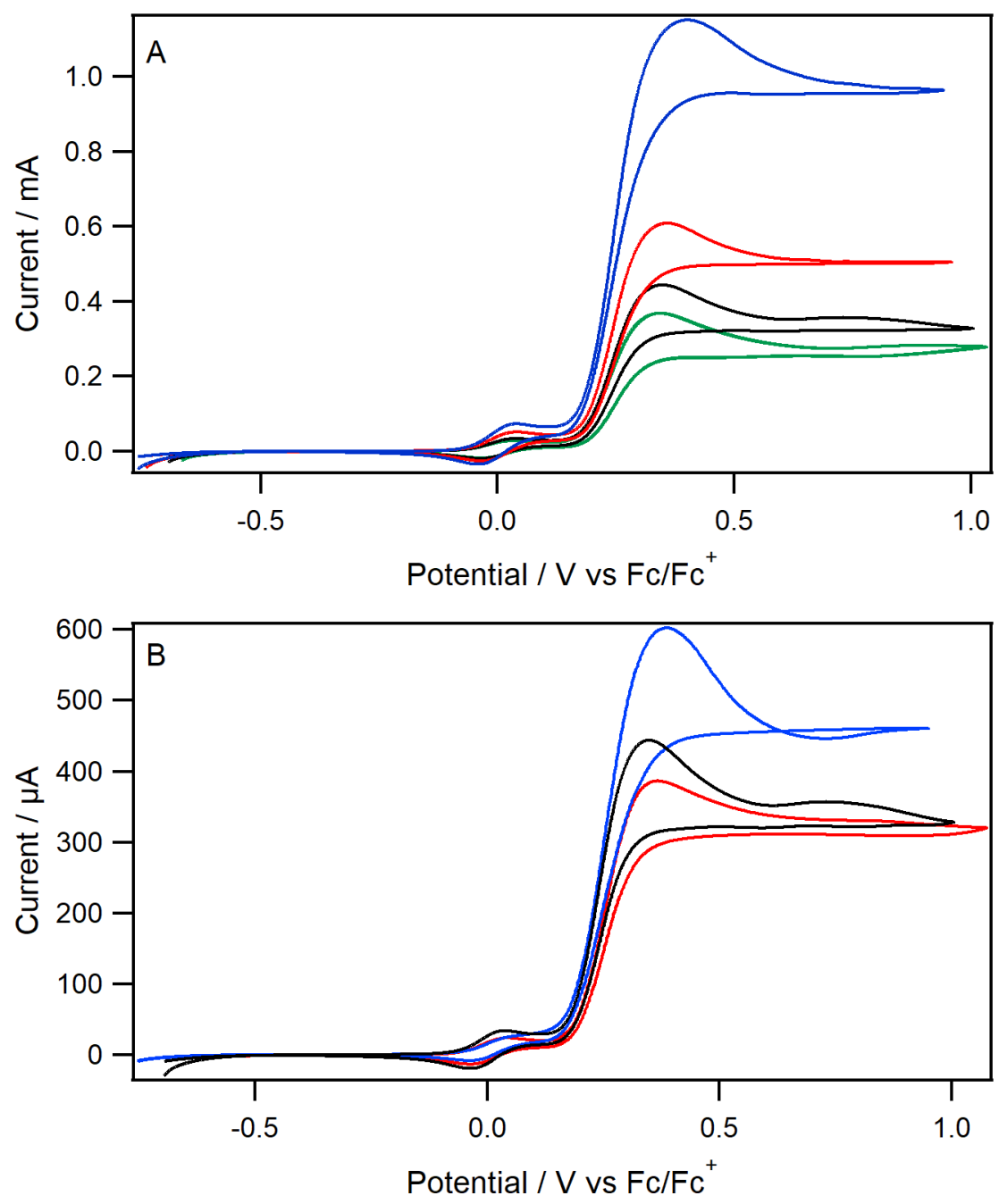

Figure 7. (A) CVs of solutions containing $0.06 \mathrm{~mol} \mathrm{dm}^{-3}$ TEMPO, $0.6 \mathrm{~mol} \mathrm{dm}^{-3}$ benzyl alcohol and $4.0 \mathrm{~mol} \mathrm{dm}^{-3}$ (blue), $3.0 \mathrm{~mol} \mathrm{dm}^{-3}$ (red), $2.0 \mathrm{~mol} \mathrm{dm}^{-3}$ (black) and $1.5 \mathrm{~mol} \mathrm{dm}^{-3}$ (green) 2,6lutidine in $\left[\mathrm{C}_{8} \mathrm{C}_{1} \mathrm{Im}\right]\left[\mathrm{NTf}_{2}\right]$. (B) CVs of solutions containing $0.06 \mathrm{~mol} \mathrm{dm}^{-3} \mathrm{TEMPO}, 0.6 \mathrm{~mol} \mathrm{dm}^{-}$ ${ }^{3}$ benzyl alcohol and $2.0 \mathrm{~mol} \mathrm{dm}^{-3}$ 2,4,6-collidine, $\mathrm{p} K_{\mathrm{aH}}=7.43$ (blue), $2.0 \mathrm{~mol} \mathrm{dm}^{-3}$ 2,6-lutidine, $\mathrm{p} K_{\mathrm{aH}}=6.75$ (black), and $2.0 \mathrm{~mol} \mathrm{dm}^{-3}$ pyridine, $\mathrm{p} K_{\mathrm{aH}}=5.25$ (red).

We tested the effect of the concentration of the added base on the electrocatalytic process and Figure 7A shows that $i_{\text {cat }}$ increases with increasing concentration of 2,6-lutidine. As the concentration of 2,6-lutidine is increased, the viscosity decreases resulting in the higher $i_{\text {cat }}$ values. 
The increase in rates of mass transfer is evident by comparing the $\mathrm{Fc} / \mathrm{Fc}^{+}$waves in the voltammograms. The relative increase in $i_{\text {cat }}$ as the concentration of 2,6-lutidine increases is drastically higher than that of the $\mathrm{Fc} / \mathrm{Fc}^{+}$peaks, demonstrating that the increase in the catalytic rate is due to a combination of the increased mass transfer in the solution and a higher $k$. We also performed our voltammetric analysis in reaction mixtures containing 2,4,6-collidine $\left(\mathrm{p} K_{\mathrm{aH}}=7.43\right)$ and pyridine $\left(\mathrm{p} K_{\mathrm{aH}}=5.25\right)$, instead of 2,6-lutidine $\left(\mathrm{p} K_{\mathrm{aH}}=6.75\right)$ as the base, and Figure 7B shows that $i_{\text {cat }}$ increases as the $\mathrm{p} K_{\mathrm{aH}}$ of the base increases. These effects have been observed previously when using organic ${ }^{21,22}$ aqueous $^{28}$ and RTIL media. ${ }^{21,34}$ The increase in $i_{\text {cat }}$ with increasing concentration and increasing $\mathrm{p} K_{\mathrm{aH}}$ of the base is because both the alcohol and hydroxylammonium species are deprotonated more rapidly, giving the reactive alcoholate anion, which is oxidized by $\mathrm{TEMPO}^{+} .21$

The selectivity of the process was determined by performing TEMPO-mediated electrocatalytic oxidations of phenylethanol, 1-octanol, and 2-butanol in $\left[\mathrm{C}_{8} \mathrm{C}_{1} \operatorname{Im}\right]\left[\mathrm{NTf}_{2}\right]$ and $\left[\mathrm{C}_{8} \mathrm{C}_{1} \mathrm{Im}\right][\mathrm{DCA}]$ (chosen as the best- and worst-performing RTIL anions during oxidation of benzyl alcohol). $k$ in $\left[\mathrm{C}_{8} \mathrm{C}_{1} \operatorname{Im}\right]\left[\mathrm{NTf}_{2}\right]$ (blue bars) and $\left[\mathrm{C}_{8} \mathrm{C}_{1} \mathrm{Im}\right][\mathrm{DCA}]$ (red bars) are shown in Figure 8. $k$ generally increases in the order 2-butanol $<1$-phenylethanol $<$ octanol $<$ benzyl alcohol, due to the lower degree of steric hindrance during reaction of the alcohol. ${ }^{21,22,28}$ Figure 8 also shows that the $\left[\mathrm{C}_{8} \mathrm{C}_{1} \mathrm{Im}\right]\left[\mathrm{NTf}_{2}\right] /$ TEMPO system was more kinetically selective than the $\left[\mathrm{C}_{8} \mathrm{C}_{1} \mathrm{Im}\right][\mathrm{DCA}] /$ TEMPO system in the oxidation of different alcohols. This different degree of discrimination between the RTILs indicates that the reaction selectivity can be tuned by the choice 


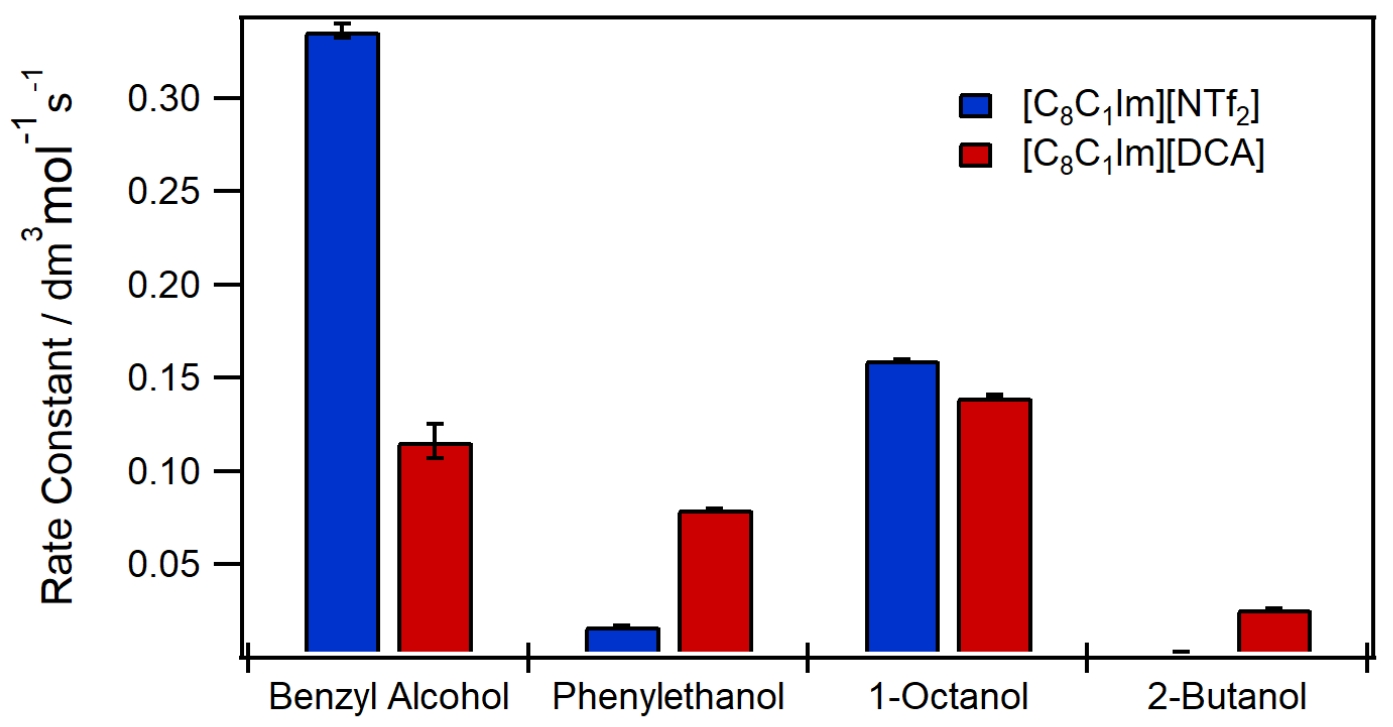

Figure 8. TEMPO-mediated alcohol oxidation rates constants for benzyl alcohol, phenylethanol, 2-butanol, and 1-octanol in $\left[\mathrm{C}_{8} \mathrm{C}_{1} \operatorname{Im}\right]\left[\mathrm{NTf}_{2}\right]$ and $\left[\mathrm{C}_{8} \mathrm{C}_{1} \operatorname{Im}\right][\mathrm{DCA}]$.

of RTIL media, which demonstrates some of the opportunities offered by RTIL/TEMPO solventelectrocatalyst systems for sustainable and selective alcohol oxidations.

TEMPO-mediated Alcohol Oxidations in Acetonitrile. To allow comparison with the state of the art, TEMPO-mediated alcohol oxidation in acetonitrile containing tetraethylammonium tetrafluoroborate, $[\mathrm{TEA}]\left[\mathrm{BF}_{4}\right]$, was investigated. Due to the lower viscosity of acetonitrile, mass transfer is typically faster than in RTILs, resulting in more rapid and efficient electrooxidation if the chemical steps are fast. However, if the kinetics of alcohol oxidation in RTILs are faster than in acetonitrile, this could potentially compensate for the slow mass transfer in RTILs and result in a higher rate of catalysis. ${ }^{21}$ Figure 9 benzyl-alcohol oxidation CVs recorded using acetonitrile $/ 0.05 \mathrm{~mol} \mathrm{dm}^{-3}[\mathrm{TEA}]\left[\mathrm{BF}_{4}\right]$ and $\left[\mathrm{C}_{8} \mathrm{C}_{1} \mathrm{Im}\right]\left[\mathrm{NTf}_{2}\right]$, respectively. $i_{\text {cat }}$ 


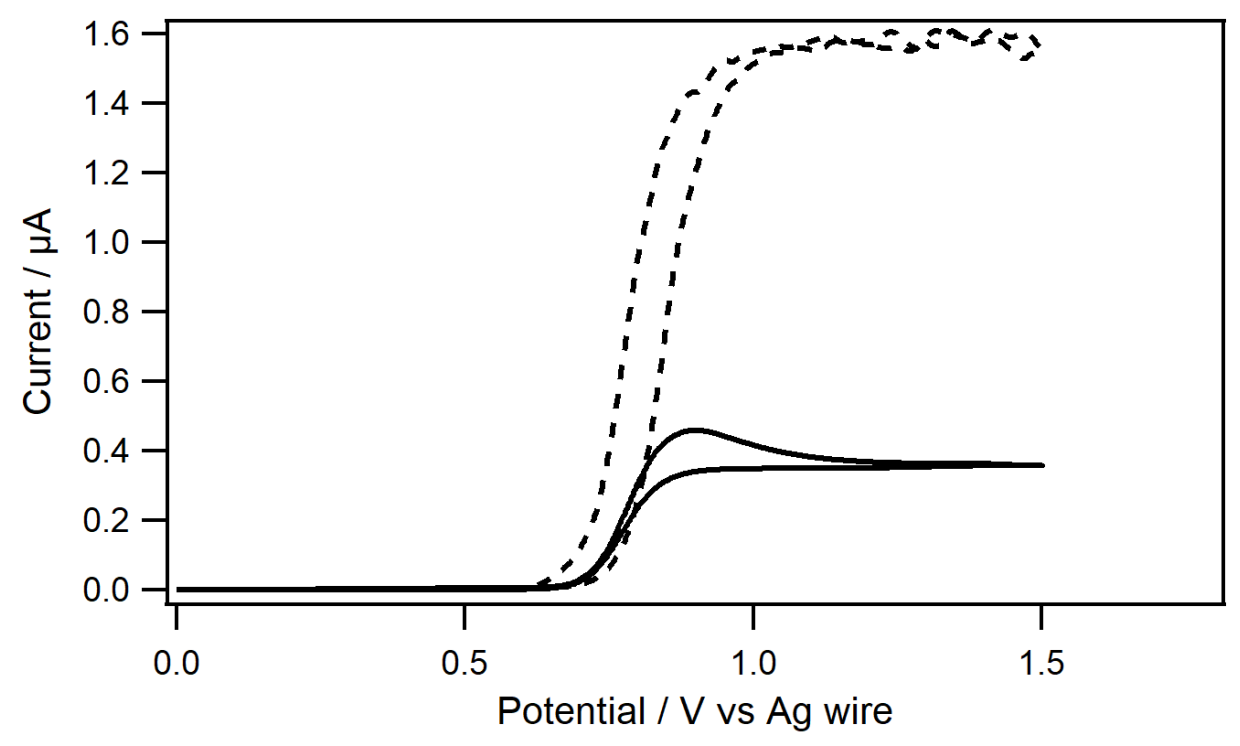

Figure 9. CVs of $60 \mathrm{mmol} \mathrm{dm}^{-3}$ TEMPO, $0.6 \mathrm{~mol} \mathrm{dm}^{-3}$ benzyl alcohol, and $2.4 \mathrm{~mol} \mathrm{dm}^{-3} 2,6-$ lutidine in $\left[\mathrm{C}_{8} \mathrm{C}_{1} \mathrm{Im}\right]\left[\mathrm{NTf}_{2}\right]$ (solid line) and in acetonitrile containing $0.05 \mathrm{~mol} \mathrm{dm}^{-3}[\mathrm{TEA}]\left[\mathrm{BF}_{4}\right]$ (dashed line), recorded at $5 \mathrm{mV} \mathrm{s}^{-1}$.

in the acetonitrile system is higher than in the $\left[\mathrm{C}_{8} \mathrm{C}_{1} \mathrm{Im}\right]\left[\mathrm{NTf}_{2}\right]$ system, which reflects the relative mass-transfer rates in the media. However, using the analysis described above and Equation $1, k$ $=0.336 \pm 0.004 \mathrm{dm}^{3} \mathrm{~mol}^{-1} \mathrm{~s}^{-1}$ in $\left[\mathrm{C}_{8} \mathrm{C}_{1} \mathrm{Im}\right]\left[\mathrm{NTf}_{2}\right]$, compared to $k=0.249 \pm 0.004 \mathrm{dm}^{3} \mathrm{~mol}^{-1} \mathrm{~s}^{-1}$ in acetonitrile. The concentration of $[\mathrm{TEA}]\left[\mathrm{BF}_{4}\right]$ in acetonitrile was increased to explore the role of the electrolyte in catalysis and Figure 10 (black squares) shows that $k$ decreases as the concentration of $[\mathrm{TEA}]\left[\mathrm{BF}_{4}\right]$ increases. These data suggest that increasing amounts of electrolyte increases interactions with $\mathrm{TEMPO}^{+}$, making it less available to participate in the catalytic cycle. Similar decreases in $k$ are observed when $\left[\mathrm{C}_{8} \mathrm{C}_{1} \operatorname{Im}\right]\left[\mathrm{NTf}_{2}\right],\left[\mathrm{C}_{8} \mathrm{C}_{1} \mathrm{Im}\right]\left[\mathrm{BF}_{4}\right]$ and $\left[\mathrm{C}_{8} \mathrm{C}_{1} \operatorname{Im}\right][\mathrm{DCA}]$ are used as dissolved electrolytes in acetonitrile at increasing concentrations (Figure 10 blue dots, 


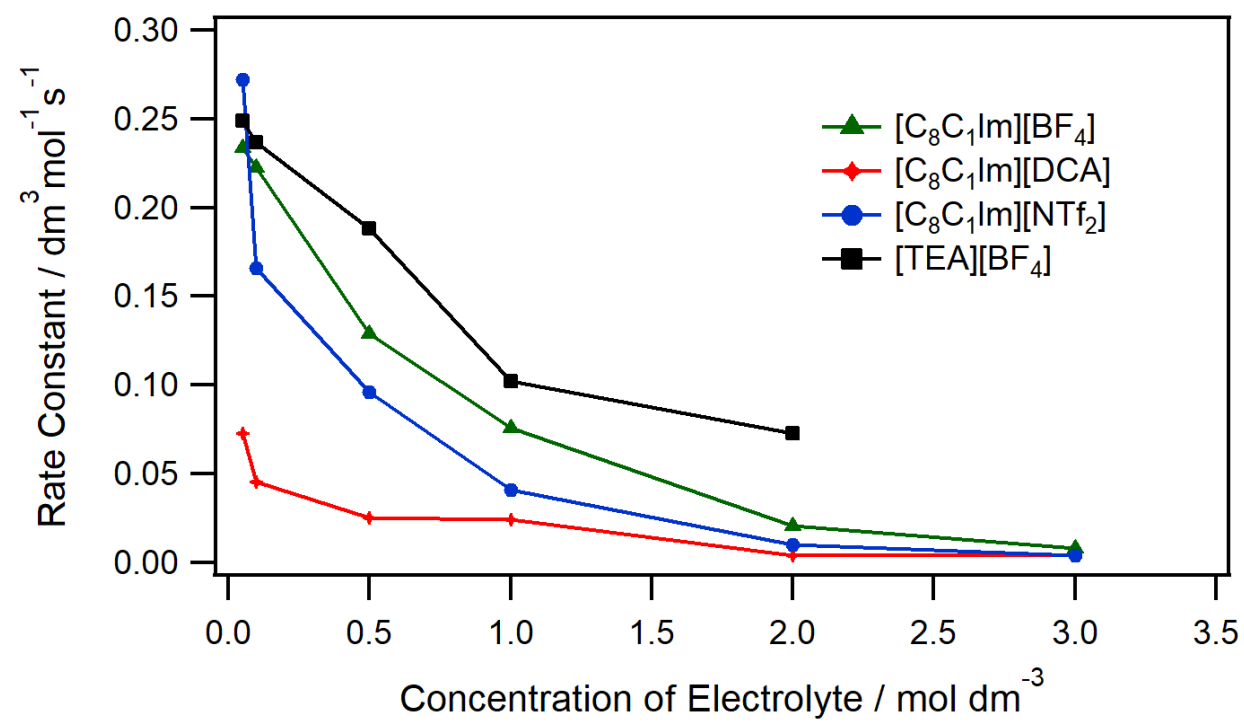

Figure 10. Rate constants for benzyl-alcohol oxidations in acetonitrile containing various concentrations of $[\mathrm{TEA}]\left[\mathrm{BF}_{4}\right],\left[\mathrm{C}_{8} \mathrm{C}_{1} \mathrm{Im}\right]\left[\mathrm{BF}_{4}\right],\left[\mathrm{C}_{8} \mathrm{C}_{1} \mathrm{Im}\right]\left[\mathrm{NTf}_{2}\right]$ and $\left[\mathrm{C}_{8} \mathrm{C}_{1} \mathrm{Im}\right][\mathrm{DCA}]$. Rate constants were determined using Equation 1 and by measuring $i_{\text {cat }}$ at different concentrations of benzyl alcohol $\left(0.3 \mathrm{~mol} \mathrm{dm}^{-3}, 0.6 \mathrm{~mol} \mathrm{dm}^{-3}, 1.2 \mathrm{~mol} \mathrm{dm}^{-3}\right.$ and $\left.2.4 \mathrm{~mol} \mathrm{dm}^{-3}\right)$, with $2.4 \mathrm{~mol} \mathrm{dm}^{-3}$ 2,6-lutidine, $0.06 \mathrm{~mol} \mathrm{dm}^{-3}$ TEMPO.

green triangles, and red diamonds, respectively). $k$ is generally lower than in neat RTILs when the concentration is $>0.05 \mathrm{~mol} \mathrm{dm}^{-3}$ and, interestingly, is similar to that in neat RTILs when the concentration is $0.05 \mathrm{~mol} \mathrm{dm}^{-3}$, potentially suggesting that the environments within the dilute electrolyte and neat RTILs are similar. A lot of recent work has addressed the nature of the ionic environment within RTILs. For example, recent surface-force measurements have indicated that RTILs behave as dilute electrolytes, ${ }^{35}$ containing long-lived ion pairs and relatively low numbers of free ions. However, there is some disagreement on the true "ionicity" of RTILs, ${ }^{36-40}$ and recent computational modelling led to the conclusion that RTILs behave not as dilute electrolytes, but as concentrated electrolytes. ${ }^{41}$ While a lot more work on this topic is needed, the data described 
here suggest that electrochemical analyses such as that described here could potentially provide some new insights into the nature of RTILs.

Flow Electrolysis. Preparative-scale, constant-current electrolysis was conducted in order to determine the efficiency and selectivity of the catalytic TEMPO-mediated alcohol oxidations in RTILs. Products emanating from the flow cell were recovered from the RTIL medium by extraction into toluene and were analyzed using GC analysis. Table 2 shows flow electrolysis data for the oxidation of benzyl alcohol in $\left[\mathrm{C}_{8} \mathrm{C}_{1} \operatorname{Im}\right]\left[\mathrm{NTf}_{2}\right]$ and $\left[\mathrm{C}_{8} \mathrm{C}_{1} \operatorname{Im}\right][\mathrm{DCA}]$ at different current densities (Scheme 1). At $0.5 \mathrm{~mA} \mathrm{~cm}^{-2}$ in $\left[\mathrm{C}_{8} \mathrm{C}_{1} \operatorname{Im}\right]\left[\mathrm{NTf}_{2}\right]$, relatively poor yields are observed and, at the highest current density of $2 \mathrm{~mA} \mathrm{~cm}{ }^{-2}$, selectivity drops to $93 \%$, indicating that competing reactions occur at higher currents.<smiles>OCc1ccccc1</smiles>

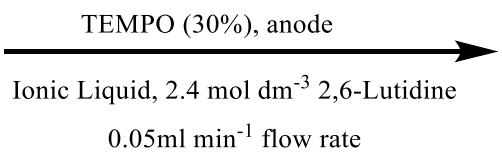<smiles>O=Cc1ccccc1</smiles>

Scheme 1: Benzyl alcohol oxidation to benzaldehyde. 
Table 2: Measured conversions and yields of flow TEMPO-mediated electroxidation of benzyl alcohol (1) in $\left[\mathrm{C}_{8} \mathrm{C}_{1} \mathrm{Im}\right]\left[\mathrm{NTf}_{2}\right]$ and $\left[\mathrm{C}_{8} \mathrm{C}_{1} \mathrm{Im}\right][\mathrm{DCA}]$ at a constant flow rate of $0.05 \mathrm{~cm}^{3} \mathrm{~min}^{-1}$, measured at different current densities.

\begin{tabular}{|c|c|c|c|}
\hline Ionic Liquid & $\begin{array}{c}\text { Current density / mA } \\
\mathrm{cm}^{-2}\end{array}$ & $\begin{array}{c}\text { Yield of } \\
\text { benzaldehyde } / \%\end{array}$ & Selectivity $/ \%$ \\
\hline$\left[\mathrm{C}_{8} \mathrm{C}_{1} \mathrm{Im}\right]\left[\mathrm{NTf}_{2}\right]$ & 0.5 & 76 & 100 \\
& 1 & 85 & 100 \\
& 1.5 & 100 & 100 \\
\hline$\left[\mathrm{C}_{8} \mathrm{C}_{1} \mathrm{Im}\right][\mathrm{DCA}]$ & 0.5 & 93 & 93 \\
& 1 & 55 & 95 \\
& 1.5 & 92 & 92 \\
\hline
\end{tabular}

${ }^{a}$ Yields were determined by using GC-FID against calibration curves of benzyl alcohol, benzaldehyde and

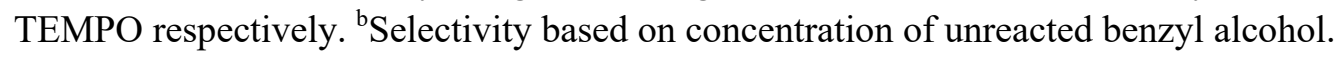

Overall, better yields and selectivities are observed when the reaction is performed in $\left[\mathrm{C}_{8} \mathrm{C}_{1} \mathrm{Im}\right]\left[\mathrm{NTf}_{2}\right]$ than when performed in $\left[\mathrm{C}_{8} \mathrm{C}_{1} \mathrm{Im}\right][\mathrm{DCA}]$. The difference in performance is likely due to a combination of faster mass transfer and reaction rates in $\left[\mathrm{C}_{8} \mathrm{C}_{1} \operatorname{Im}\right]\left[\mathrm{NTf}_{2}\right](D$ and $k$ in $\left[\mathrm{C}_{8} \mathrm{C}_{1} \mathrm{Im}\right]\left[\mathrm{NTf}_{2}\right]$ and $\left[\mathrm{C}_{8} \mathrm{C}_{1} \operatorname{Im}\right][\mathrm{DCA}]$ are shown in Tables $\mathrm{S} 10$ and $\mathrm{S} 2$, respectively). The lower selectivities in $\left[\mathrm{C}_{8} \mathrm{C}_{1} \operatorname{Im}\right][\mathrm{DCA}]$ suggest that competing reactions occur in $\left[\mathrm{C}_{8} \mathrm{C}_{1} \mathrm{Im}\right][\mathrm{DCA}]$.

When the electrolysis is performed at lower flow rates $\left(>0.05 \mathrm{~cm}^{3} \mathrm{~min}^{-1}\right)$ and higher current densities $\left(>2 \mathrm{~mA} \mathrm{~cm}^{-2}\right)$, the $\left[\mathrm{C}_{8} \mathrm{C}_{1} \mathrm{Im}\right][\mathrm{DCA}]$ and $\left[\mathrm{C}_{8} \mathrm{C}_{1} \mathrm{Im}\right]\left[\mathrm{NTf}_{2}\right]$ solutions changed color from light orange to dark brown. Furthermore, a clear loss of TEMPO from the GC chromatograms was observed. Previous studies have observed that the imidazolium cation is susceptible to oxidation to an imidazole radical species, ${ }^{42,}{ }^{43}$ which could be one of the competing reactions in the 
electrolysis. Considering that TEMPO is known to scavenge carbon-centered radicals, ${ }^{44}$ if any imidazole radical is formed it will react with TEMPO, which can explain the loss of TEMPO. However, at lower current densities and higher flow rates, the solution did not change color and better faradaic selectivities were obtained.

To investigate how the efficiency of the TEMPO-mediated alcohol oxidations in RTILs compares to alcohol oxidations in acetonitrile, flow electrolysis of benzyl alcohol oxidation was conducted in acetonitrile containing $1 \mathrm{~mol} \mathrm{dm}^{-3}\left[\mathrm{C}_{8} \mathrm{C}_{1} \mathrm{Im}\right]\left[\mathrm{NTf}_{2}\right]$ (see Table 3 ). Despite the fact that $\left[\mathrm{C}_{8} \mathrm{C}_{1} \mathrm{Im}\right]\left[\mathrm{NTf}_{2}\right]$ is more viscous than acetonitrile, the product yields are similar or only slightly lower than when the oxidation is performed in acetonitrile containing $1 \mathrm{~mol} \mathrm{dm}^{-3}$ $\left[\mathrm{C}_{8} \mathrm{C}_{1} \mathrm{Im}\right]\left[\mathrm{NTf}_{2}\right]\left(D\right.$ in acetonitrile is $\left.17.1 \times 10^{-10} \pm 0.5 \times 10^{-10} \mathrm{~m}^{2} \mathrm{~s}^{-1}\right)$. As shown in the previous section, $k$ in $\left[\mathrm{C}_{8} \mathrm{C}_{1} \operatorname{Im}\right]\left[\mathrm{NTf}_{2}\right]\left(0.336 \mathrm{dm}^{-3} \mathrm{~mol}^{-1} \mathrm{~s}^{-1}\right)$ is greater than in in $1 \mathrm{~mol} \mathrm{dm}^{-3}\left[\mathrm{C}_{8} \mathrm{C}_{1} \operatorname{Im}\right]\left[\mathrm{NTf}_{2}\right]$ in acetonitrile $\left(0.04 \mathrm{dm}^{-3} \mathrm{~mol}^{-1} \mathrm{~s}^{-1}\right)$. The higher $k$ in $\left[\mathrm{C}_{8} \mathrm{C}_{1} \mathrm{Im}\right]\left[\mathrm{NTf}_{2}\right]$ seems to compensate for the slower mass transfer and results in comparative yields as when the oxidation is performed in acetonitrile. This observation demonstrates the viability of replacing volatile organic solvents and electrolyte systems with RTILs as the media for TEMPO-mediated alcohol oxidations without the loss of efficiency of the reaction due to slower mass transfer. 
Table 3: Measured conversions and yields of the flow TEMPO-mediated electroxidation of benzyl alcohol (1) in acetonitrile with $1 \mathrm{~mol} \mathrm{dm}^{-3}\left[\mathrm{C}_{8} \mathrm{C}_{1} \mathrm{Im}\right]\left[\mathrm{NTf}_{2}\right]$ at a constant flow rate of $0.05 \mathrm{~cm}^{3} \mathrm{~min}^{-}$ 1 , measured at different current densities.

\begin{tabular}{|c|c|c|c|}
\hline Electrolyte & $\begin{array}{c}\text { Current density / mA } \\
\mathrm{cm}^{-2}\end{array}$ & $\begin{array}{c}\text { Yield of } \\
\text { Benzaldehyde } / \%\end{array}$ & Selectivity $\%$ \\
\hline 1.5 & 61 & 100 \\
$\left.1 \mathrm{~mol} \mathrm{dm}_{8} \mathrm{C}_{1} \mathrm{Im}\right]\left[\mathrm{NTf}_{2}\right]$ & 1 & 99 & 100 \\
& 1.5 & 100 & 100 \\
& 2 & 100 & 62 \\
\hline
\end{tabular}

${ }^{a}$ Yields were determined by using GC-FID against calibration curves of benzyl alcohol, benzaldehyde and TEMPO respectively. ${ }^{b}$ Selectivity based on concentration of unreacted benzyl alcohol.

To investigate the reaction selectivities in RTILs, electrolysis of a mixture of a primary alcohol and a secondary alcohol was conducted. Table 4 shows flow electrolysis data for the oxidation of a mixture of benzyl alcohol (primary) and 1-phenylethanol (secondary) in $\left[\mathrm{C}_{8} \mathrm{C}_{1} \operatorname{Im}\right]\left[\mathrm{NTf}_{2}\right],\left[\mathrm{C}_{8} \mathrm{C}_{1} \operatorname{Im}\right][\mathrm{DCA}]$ and acetonitrile containing $1 \mathrm{~mol} \mathrm{dm}^{-3}\left[\mathrm{C}_{8} \mathrm{C}_{1} \operatorname{Im}\right]\left[\mathrm{NTf}_{2}\right]$ at 1.5 $\mathrm{mA} \mathrm{cm}{ }^{-2}$ (Scheme 2).

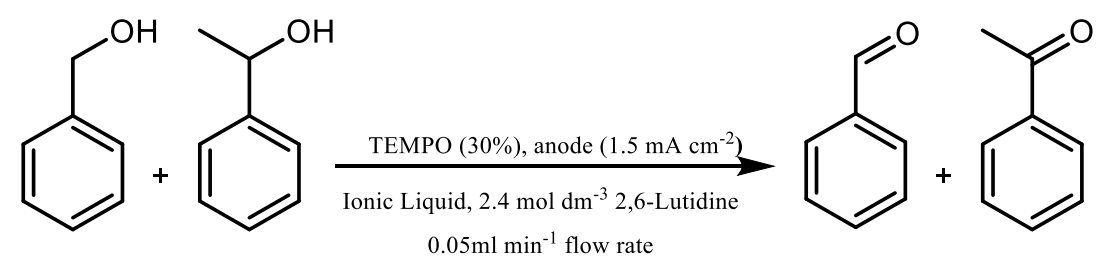

Scheme 2: oxidation of benzyl alcohol and phenylethanol to benzaldehyde and acetophenone. 
Table 4: Measured conversions, yields and selectivities of the flow TEMPO-mediated electroxidation of a mixture of benzyl alcohol (1) and phenylethanol (2) in $\left[\mathrm{C}_{8} \mathrm{C}_{1} \operatorname{Im}\right][\mathrm{NTf} 2]$, $\left[\mathrm{C}_{8} \mathrm{C}_{1} \mathrm{Im}\right][\mathrm{DCA}]$ and acetonitrile with $1 \mathrm{~mol} \mathrm{dm}^{-3}\left[\mathrm{C}_{8} \mathrm{C}_{1} \mathrm{Im}\right]\left[\mathrm{NTf}_{2}\right]$ at a constant flow rate of 0.05 $\mathrm{cm}^{3} \mathrm{~min}^{-1}$.

\begin{tabular}{|c|c|c|c|}
\hline Ionic Liquid & $\begin{array}{c}\text { Yield of Benzaldehyde } \\
\%\end{array}$ & $\begin{array}{c}\text { Yield of } \\
\text { Acetophenone }^{\mathrm{a}} / \%\end{array}$ & $\begin{array}{c}\text { Selectivity of } \\
\text { Benzaldehyde } / \%^{*}\end{array}$ \\
\hline$\left[\mathrm{C}_{8} \mathrm{C}_{1} \mathrm{Im}\right]\left[\mathrm{NTf} \mathrm{N}_{2}\right]$ & 96 & 16 & 83 \\
\hline$\left[\mathrm{C}_{8} \mathrm{C}_{1} \mathrm{Im}\right][\mathrm{DCA}]$ & 100 & 39 & 61 \\
\hline $\begin{array}{c}1 \mathrm{~mol} \mathrm{dm}{ }^{-3} \\
{\left[\mathrm{C}_{8} \mathrm{C}_{1} \mathrm{Im}\right]\left[\mathrm{NTf}_{2}\right] \text { in }} \\
\text { acetonitrile }\end{array}$ & 100 & 72 & 28 \\
\hline
\end{tabular}

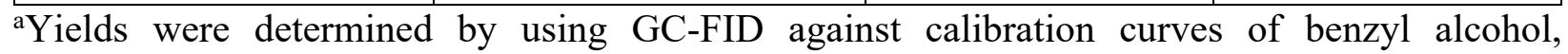
phenylethanol, benzaldehyde and acetophenone.

A clear selectivity towards primary alcohols is observed, and the best selectivity is observed when the electrolysis is performed in $\left[\mathrm{C}_{8} \mathrm{C}_{1} \operatorname{Im}\right]\left[\mathrm{NTf}_{2}\right]$. The selectivity is slightly poorer when the electrolysis is performed in $\left[\mathrm{C}_{8} \mathrm{C}_{1} \operatorname{Im}\right][\mathrm{DCA}]$. This difference in selectivity is also seen in the calculated rate constants as discussed in previous section. The selectivity was, however, very poor when the alcohol oxidation was performed in acetonitrile containing $1 \mathrm{~mol} \mathrm{dm}^{-3}$ $\left[\mathrm{C}_{8} \mathrm{C}_{1} \mathrm{Im}\right]\left[\mathrm{NTf}_{2}\right]$. In previous studies, it has been demonstrated that, despite the slower chemistry, secondary alcohols are oxidized efficiently with excellent yields using the same conditions as for oxidation of the primary alcohol analogue. For example, the electrolysis of primary alcohol 4methoxybenzyl alcohol yielded 4-methoxybenzaldehyde at $88 \%$ yield and electrolysis of the secondary alcohol 1-(4-methoxyphenyl)ethanol yielded 92\% of 1-(4-methoxyphenyl)ethanone, under the same conditions. ${ }^{28}$ Stahl and coworkers showed that the TEMPO modified 4-acetamidoTEMPO, electrooxidation of benzyl alcohol and 1-phenylethanol yielded $88 \%$ of benzaldehyde and $88 \%$ acetophenone respectively (in two separate experiments) using identical conditions and 
electrolysis time. ${ }^{27}$ These results demonstrate good reaction efficiency of oxidation secondary alcohols, however it also demonstrates poor alcohol selectivity of TEMPO.

\section{Conclusion}

The redox properties of TEMPO have been investigated using a range of ionic liquids as the electrochemical solvents. Cyclic voltammetry revealed that the TEMPO/TEMPO ${ }^{+}$redox potential depended on the composition of the ionic liquid, due to differing degrees of stabilization of the TEMPO ${ }^{+}$cations. The variation in the degree of interaction between the RTIL solvent and the catalytically-active $\mathrm{TEMPO}^{+}$led to significant differences in catalytic activity of TEMPO during oxidation of alcohols in ionic liquids. The catalytic reaction rate constant increased with increasing TEMPO/TEMPO ${ }^{+}$potential, and could be correlated with decreasing RTIL-anion $\mathrm{H}-$ bond basicity. Comparison of the rates of catalytic oxidation of four different alcohols substrates revealed different degrees of catalytic discrimination in the ionic liquids, confirming that the activity of TEMPO can be controlled by the choice of the ionic liquid. Electrochemical TEMPOmediated oxidations in ionic liquids offer an alcohol oxidation route with a higher atom efficiency than in conventional alcohol oxidations in that (1) coupling electrochemistry with TEMPO minimizes the input of stoichiometric or hazardous reagents during oxidations, (2) the use of ionic liquids as the solvent and electrolyte reduces the amount of required reagents for the electrosynthesis. The redox catalytic oxidation of alcohols in RTIL with low H-bond basicity anions, such as $\left[\mathrm{NTf}_{2}\right]^{-}$is particularly advantageous as highly efficient processing can be carried out catalytically in the absence of secondary oxidant, volatile molecular solvents and electrolyte salts. It is also significant that the global rate constant for the oxidation rate constant for the oxidation reaction is larger in RTILs with low H-bond basicity anions than that observed in acetonitrile. 


\section{Acknowledgements}

We thank the Engineering and Physical Sciences Research Council for funding (Grants EP/L015633/1 and EP/P002382/1).

\section{Supporting Information}

Complete voltammetric data, bulk-electrolysis data and some additional experimental details.

\section{References}

(1) Alfonsi, K.; Colberg, J.; Dunn, P. J.; Fevig, T.; Jennings, S.; Johnson, T. A.; Kleine, H. P.; Knight, C.; Nagy, M. A.; Perry, D. A.; Stefaniak, M., Green Chemistry Tools to Influence a Medicinal Chemistry and Research Chemistry Based Organisation. Green Chem. 2008, 10, $31-36$

(2) Ohsugi, S.-i.; Nishide, K.; Oono, K.; Okuyama, K.; Fudesaka, M.; Kodama, S.; Node, M., New Odorless Method for the Corey-Kim and Swern Oxidations Utilizing Dodecyl Methyl Sulfide (Dod-S-Me). Tetrahedron 2003, 59, 8393-8398.

(3) Thottumkara, A. P.; Vinod, T. K., Synthesis and Oxidation Reactions of a User- and EcoFriendly Hypervalent Iodine Reagent. Tetrahedron Lett. 2002, 43, 569-572.

(4) Constable, D. J. C.; Dunn, P. J.; Hayler, J. D.; Humphrey, G. R.; Leazer, J. J. L.; Linderman, R. J.; Lorenz, K.; Manley, J.; Pearlman, B. A.; Wells, A.; Zaks, A.; Zhang, T. Y., Key Green Chemistry Research Areas - A Perspective from Pharmaceutical Manufacturers. Green Chem. 2007, 9, 411-420. 
(5) Corberan, V. C.; Gonzalez-Perez, M. E.; Martinez-Gonzalez, S.; Gomez-Aviles, A., Green Oxidation of Fatty Alcohols: Challenges and Opportunities. Appl. Catal., A. 2014, 474, 211223.

(6) Sheldon, R. A.; Arends, I., Catalytic Oxidations Mediated by Metal Ions and Nitroxyl Radicals. J. Mol. Catal., A. 2006, 251, 200-214.

(7) Sheldon, R. A.; Arends, I.; Ten Brink, G. J.; Dijksman, A., Green, Catalytic Oxidations of Alcohols. Acc. Chem. Res. 2002, 35, 774-781.

(8) Sheldon, R. A., Recent Advances in Green Catalytic Oxidations of Alcohols in Aqueous Media. Catal. Today. 2015, 247, 4-13.

(9) Yan, M.; Kawamata, Y.; Baran, P. S., Synthetic Organic Electrochemical Methods since 2000: On the Verge of a Renaissance. Chem. Rev. 2017, 117, 13230-13319.

(10) Pletcher, D., Organic Electrosynthesis - A Road to Greater Application. A Mini Review. Electrochem. Commun. 2018, 88, 1-4.

(11) Cardoso, D. S. P.; Šljukić, B.; Santos, D. M. F.; Sequeira, C. A. C., Organic Electrosynthesis: From Laboratorial Practice to Industrial Applications. Org. Process Res. Dev. 2017, 21, 1213-1226.

(12) Anelli, P. L.; Montanari, F.; Quici, S., A General Synthetic Method for the Oxidation of Primary Alcohols to Aldehydes: (S)-(+)-2-Methylbutanal. In Organic Syntheses, John Wiley \& Sons, Inc.: 2003.

(13) Ciriminna, R.; Ghahremani, M.; Karimi, B.; Pagliaro, M., Electrochemical Alcohol Oxidation Mediated by Tempo-Like Nitroxyl Radicals. ChemistryOpen. 2017, 6, 5-10.

(14) Kathiresan, M.; Velayutham, D., Ionic Liquids as an Electrolyte for the Electro Synthesis of Organic Compounds. Chem. Commun. 2015, 51, 17499-17516. 
(15) Lahiri, A.; Borisenko, N.; Endres, F., Electrochemical Synthesis of Battery Electrode Materials from Ionic Liquids. Top. Curr. Chem. 2018, 376, 29.

(16) Amaral, L.; Cardoso, D.S.P.; Šljukić, B.; Santos, D.M.F.; Sequeira, C.A.C., Electrochemistry of Hydrogen Evolution in Ionic Liquids Aqueous Mixtures. Mater. Res. Bull. 2019, 112, 407412.

(17) Newington, I.; Perez-Arlandis, J. M.; Welton, T., Ionic Liquids as Designer Solvents for Nucleophilic Aromatic Substitutions. Org. Lett. 2007, 9, 5247-5250.

(18) Buzzeo, M. C.; Klymenko, O. V.; Wadhawan, J. D.; Hardacre, C.; Seddon, K. R.; Compton, R. G., Voltammetry of Oxygen in the Room-Temperature Ionic Liquids 1-Ethyl-3Methylimidazolium Bis((Trifluoromethyl)Sulfonyl)Imide and Hexyltriethylammonium Bis((Trifluoromethyl)Sulfonyl)Imide: One-Electron Reduction to Form Superoxide. SteadyState and Transient Behavior in the Same Cyclic Voltammogram Resulting from Widely Different Diffusion Coefficients of Oxygen and Superoxide. J. Phys. Chem., A. 2003, 107, $8872-8878$.

(19) Taylor, A. W.; Puttick, S.; Licence, P., Probing Solvation in Ionic Liquids Via the Electrochemistry of the Dpph Radical. J. Am. Chem. Soc. 2012, 134, 15636-15639.

(20) Xiong, L.; Fletcher, A. M.; Davies, S. G.; Norman, S. E.; Hardacre, C.; Compton, R. G., Tuning Solute Redox Potentials by Varying the Anion Component of Room Temperature Ionic Liquids. Chem. Commun. 2012, 48, 5784-5786.

(21) Comminges, C.; Barhdadi, R.; Doherty, A. P.; O'Toole, S.; Troupel, M., Mechanism of 2,2'6,6'-Tetramethylpiperidin-N-Oxyl-Mediated Oxidation of Alcohols in Ionic Liquids. $J$. Phys. Chem., A 2008, 112, 7848-7855. 
(22) Barhdadi, R.; Comminges, C.; Doherty, A. P.; Nedelec, J. Y.; O'Toole, S.; Troupel, M., The Electrochemistry of Tempo-Mediated Oxidation of Alcohols in Ionic Liquid. J. Appl. Electrochem. 2007, 37, 723-728.

(23) Blundell, R. K.; Licence, P., Quaternary Ammonium and Phosphonium Based Ionic Liquids: A Comparison of Common Anions. Phys. Chem. Chem. Phys. 2014, 16, 15278-15288.

(24) Men, S.; Lovelock, K. R. J.; Licence, P., X-Ray Photoelectron Spectroscopy of PyrrolidiniumBased Ionic Liquids: Cation-Anion Interactions and a Comparison to Imidazolium-Based Analogues. Phys. Chem. Chem. Phys. 2011, 13, 15244-15255.

(25) Torriero, A. A. J., Characterization of Decamethylferrocene and Ferrocene in Ionic Liquids: Argon and Vacuum Effect on Their Electrochemical Properties. Electrochim. Acta. 2014, $137,235-244$.

(26) Semmelhack, M. F.; Chou, C. S.; Cortes, D. A., Nitroxyl-Mediated Electrooxidation of Alcohols to Aldehydes and Ketones. J. Am. Chem. Soc. 1983, 105, 4492-4494.

(27) Rafiee, M.; Miles, K. C.; Stahl, S. S., Electrocatalytic Alcohol Oxidation with Tempo and Bicyclic Nitroxyl Derivatives: Driving Force Trumps Steric Effects. J. Am. Chem. Soc. 2015, $137,14751-14757$.

(28) Hill-Cousins, J. T.; Kuleshova, J.; Green, R. A.; Birkin, P. R.; Pletcher, D.; Underwood, T. J.; Leach, S. G.; Brown, R. C. D., Tempo-Mediated Electrooxidation of Primary and Secondary Alcohols in a Microfluidic Electrolytic Cell. ChemSusChem. 2012, 5, 326-331.

(29) Tachikawa, N.; Katayama, Y.; Miura, T., Electrode Kinetics of Ferrocenium/Ferrocene in Room-Temperature Ionic Liquids. Ecs Trans. 2009, 16, 589-595. 
(30) Cláudio, A. F. M.; Swift, L.; Hallett, J. P.; Welton, T.; Coutinho, J. A. P.; Freire, M. G., Extended Scale for the Hydrogen-Bond Basicity of Ionic Liquids. Phys. Chem. Chem. Phys. 2014, 16, 6593-6601.

(31) Spange, S.; Lungwitz, R.; Schade, A., Correlation of Molecular Structure and Polarity of Ionic Liquids. J. Mol. Liquids. 2014, 192, 137-143.

(32) Rafiee, M.; Karimi, B.; Alizadeh, S., Mechanistic Study of the Electrocatalytic Oxidation of Alcohols by Tempo and Nhpi. ChemElectroChem. 2014, 1, 455-462.

(33) Savéant, J.-M., Molecular Catalysis of Electrochemical Reactions. Mechanistic Aspects. Chem.Rev. 2008, 108, 2348-2378.

(34) Barhdadi, R.; Troupel, M.; Comminges, C.; Laurent, M.; Doherty, A., Electrochemical Determination of Pk(a) of N-Bases in Ionic Liquid Media. J. Phys. Chem., B. 2012, 116, $277-282$.

(35) A Gebbie, M.; Valtiner, M.; Banquy, X.; Fox, E.; A Henderson, W.; Israelachvili, J., Ionic Liquids Behave as Dilute Electrolyte Solutions. PNAS. 2013, 110, 9674-9679.

(36) Tokuda, H.; Baek, S.J.; Watanabe, M., Room-Temperature Ionic Liquid-Organic Solvent Mixtures: Conductivity and Ionic Association. Electrochem. 2005, 73, 620-622.

(37) Sha, M.; Dong, H.; Luo, F.; Tang, Z.; Zhu, G.; Wu, G.; Dilute or Concentrated Electrolyte Solutions? Insight from Ionic Liquid/Water Electrolytes. J. Phys. Chem. Lett., 2015, 6, 37133720.

(38) Perkin, S.; Salanne, M.; Madden, P.; Lynden-Bell, R.; Is a Stern and diffuse layer model appropriate to ionic liquids at surfaces? PNAS, 2013, 110, 4121. 
(39) Gebbie, M. A.; Valtiner, M.; Banquy, X.; Henderson, W. A.; Isrealachvili, J. N.; Reply to Perkin et al.: Experimental observations demonstrate that ionic liquids form both bound (Stern) and diffuse electric double layers. PNAS, 2015, 6, 3713-3720.

(40) Weingärtner, H.; Understanding Ionic Liquids at the Molecular Level: Facts, Problems, and Controversies. Angew. Chem., Int. Ed., 2008, 47, 654-670.

(41) Lee, A. A.; Vella, D.; Perkin, S.; Goriely, A.; Are Room-Temperature Ionic Liquids Dilute Electrolytes? J. Phys. Chem. Lett. 2015, 6, 159-163.

(42) Hallett, P. J.; Welton, T.; Room-Temperature Ionic Liquids: Solvents for Synthesis and Catalysis. 2. Chem. Rev., 2011, 111, 3508-3576.

(43) Farmer, V.; Welton, T.; The oxidation of alcohols in substituted imidazolium ionic liquids using ruthenium catalysts. Green Chem., 2002, 4, 97-102.

(44) Wright, J. P.; English, M. A.; Scavenging with TEMPO• To Identify Peptide- and ProteinBased Radicals by Mass Spectrometry: Advantages of Spin Scavenging over Spin Trapping. J. Am. Chem. Soc., 2003, 125, 8655-8665. 